\title{
A Simple Trick to Protect Your IP
}

\section{Zura Kakushadze ${ }^{1,2 *}$}

${ }^{1}$ Quantigic ${ }^{\circledR}$ Solutions LLC ${ }^{3}, 1127$ High Ridge Road, \#135, Stamford, CT 06905, USA

${ }^{2}$ Free University of Tbilisi, Business School and School of Physics, 240, David Agmashenebeli Alley, Tbilisi, 0159, Georgia

You need to submit a confidential white paper and/or computer code to your client, but want to protect your IP before sending it out.

You would like to submit a research paper to a refereed journal, but want to make sure your research is not plagiarized.

Or you simply want to discuss your ideas with colleagues, investors, etc., but wish to have the peace of mind knowing that your IP is protected.

Here's a simple trick for protecting your IP via "security by obscurity".

1. You create a trust with broad objectives, including handling your intellectual property. The trust name should be obfuscated. You can use a random password generator with all letters, e.g., "GTCJNZAM Trust". You can be the trustee and the beneficiary at the same time. Make sure the trust has no income, otherwise it will need a Tax Identification Number (TIN) - the idea here is that the trust should remain completely obfuscated. Also, unlike business structures such as limited liability companies and corporations, such a trust need not be registered. It is a legal entity that no one needs to know about.

2. You will need a mailing address for your trust. Do not use your or your company's mailing address. You can get a PO Box or a private mail forwarding service. It can be under your name and, since you are the trustee, you can also have your trust as one of the addressees. You will have to make sure not to share this address with anyone else so the trust remains $100 \%$ obfuscated.

3. Now you are ready to protect your IP. Say you have documents (a white paper, a research paper, source code... a poem... whatever else...) you want to protect. You can file a copyright registration application online (copyright.gov). However, if you file it under your own name, anyone can look it up online (once it is catalogued by the Library of Congress), go to the archives and look at it... not good... This is where your new intellectual property trust comes in handy. You file a copyright registration application with the trust as the copyright owner. It will have to be filed as work done for hire (which according to recent changes will set you back $\$ 55$ instead of $\$ 35$ had you filed it with you as the copyright owner). Everything will be under the trust name and address, which no one knows and cannot be looked up. Your name will only appear in the copyright registration application under the "correspondent" (they require a natural person for this), but the correspondent's name is not in the public domain under the registration (it is only needed for the copyright office to contact you if there is a problem; the registration certificate can be addressed to the trust at its address).

So, at the end of this process, a copy of your IP will be sitting somewhere in the archives of the Library of Congress - but there is no way for anyone to find out unless you tell them - and a copyright will be registered under the trust name, so you have your peace of mind. If you or your company need to own the copyright, simply sign the copyright over from the trust - you are the trustee - to the desired beneficiary. Such a copyright assignment need not be filed with the Copyright Office, it is a private transaction. For added peace of mind you could have the copyright assignment executed before a notary public, but this is not necessarily required.

Happy obfuscating!

DISCLAIMER: THIS ARTICLE IS FOR INFORMATIONAL PURPOSES ONLY. NOTHING CONTAINED IN THIS ARTICLE IS INTENDED TO BE OR SHOULD BE CONSTRUED AS LEGAL, TAX, INVESTMENT OR ANY OTHER SUCH ADVICE.
${ }^{3}$ DISCLAIMER: This address is used by the corresponding author for no purpose other than to indicate his professional affiliation as is customary in publications. In particular, the contents of this paper are not intended as an investment, legal, tax or any other such advice, and in no way represent views of Quantigic ${ }^{\circledR}$ Solutions LLC, the website www.quantigic.com or any of their other affiliates.
*Corresponding author: Zura Kakushadze, Quantigic ${ }^{\circledR}$ Solutions LLC, 1127 High Ridge Road, \#135, Stamford, CT 06905, USA, E-mail: zura@quantigic.com

Received August 31, 2015; Accepted September 09, 2015; Published September 19,2015

Citation: Kakushadze Z (2015) A Simple Trick to Protect Your IP. Intel Prop Rights. 3: 146. doi:10.4172/2375-4516.1000146

Copyright: (c) 2015 Zura Kakushadze. This is an open-access article distributed under the terms of the Creative Commons Attribution License, which permits unrestricted use, distribution, and reproduction in any medium, provided the original author and source are credited. 